\title{
Chemical characterization and antibacterial efficacy of Saudi sesame oil against human pathogenic bacteria
}

\author{
Alshahrani Saeed ${ }^{1}$, Alsreaya Al AseelAbid ${ }^{2}$, Mashyakhi Mohammad Yahya ${ }^{2}$, Alqahtani \\ Saad $^{3,}$ Moni Sivakumar Sivagurunathan ${ }^{4}$, Alhazmi Hassan Ahmed ${ }^{5,6}$, Rehman Ziaur ${ }^{5}$, \\ Alam Mohammad Firoz ${ }^{1}$
}

Received: 20.03.2020

Revised: 28.04.2020

Accepted: 30.04.2020

\begin{abstract}
Bacterial infection and its resistance is a major health issue that affects millions of people throughout the world. There is always a need to search forth new and safest drug from natural resources to fight these challenges. Sesame seed essential oil is a rich source of protein with high medicinal value since the ancient time peoples are using for several remedies in Saudi Arabia.Therefore, the current study is aimed to discover the potential activity of the locally available sesame oil for antibacterial action based on ethnobotanical knowledge and traditional utilization as a therapeutic agent to treat several kinds of health problem in Saudi culture. Gas chromatography / mass spectrometry (GC/MS) analysis of sesame essential oil extracted from locally available sesame seeds represented 39 different chemical compounds. Sesamin and sesamol were the principal components alongwith fatty acids and triglycerides. Results indicated that the locally available sesame oil was found rich in sesamin contents $(\mathbf{2 4 . 4 5 \%})$. The spectrum of antibacterial effect of sesame seed essential oil was exhibited significantly against Escherichia coli followed by Staphylococcus aureus, Streptococcus pyogenes, Klebsiella pneumoniae and Pseudomonas aeruginosa respectively. The results indicate that sesame oil was found most effective against three bacteria i.e. $E$. coli, $S$. aureus and $S$. pyogenes.
\end{abstract}

Key words: Antibacterial activity, ethnobotanical, GC/MS analysis, Saudi sesame oil.

\section{Introduction}

Sesame oil is the edible oil obtained from the seeds of plant Sesamumindicum L., family Pedaliaceae. Sesame is one of the oldest crops cultivated in the tropical and subtropical region for its edible oil. In Saudi Arabia, this plant is commonly known as "semsem" and is cultivated in coastal plains and mountain regions of Jazan province (Al-Turkiet al., 2019).Sesame seeds are a rich source of proteins, lignans, fatty acids and various other bioactive components and have been widely used as traditional medicine for several remedies in Saudi Arabia since ancient times (Al-Attar et al.,2017;

Author's Address

1 Department of Pharmacology and Toxicology, College of Pharmacy, Jazan University, Jazan, KSA.

${ }^{2}$ College of Pharmacy, Jazan University, Jazan, KSA.

3 Pharmacy Services Department, Security Forces Hospital, Riyadh, KSA

${ }^{4}$ Department of Pharmaceutics, College of Pharmacy, Jazan University, Jazan, KSA.

${ }^{5}$ Department of Pharmaceutical Chemistry, College of Pharmacy, Jazan University, Jazan, KSA.

${ }^{6}$ Substance of Abuse Research Center (SARC), College of Pharmacy, Jazan University, Jazan, KSA.

E-mail.: saalshahrani@jazanu.edu.sa
Koshak et al., 2019). Sesame oil has high nutritional value and used for cooking and salad dressings in various countries. In Saudi Arabia, it is an important part of kitchen contributing a significant role in the preparation of many varieties of sweetspies and taken as such with dates and olive oil (Özcan, and AL-Juhaimi, 2015). In many other South-East Asian societies, sesame oil is an important ingredient of various cosmetic products and body massage oils. Its commercialized products are available as an important ingredient in soap, cosmetics, lubricants, and medicines. In the pharmaceutical industry, sesame oil is used as an emollient, carrier oil for other essential oils and fatsoluble compounds. Sesame oil is reported to have significant antineoplastic, neuroprotective, antioxidant, anti-inflammatory and lipid-lowering activities (Deme et al., 2018; Narasimhulu et al.,2018; Majdalawiehet al.,2019; Mekkyet al., 2019; Ruankham et al., 2019). Recently a researcher hypothesized that adding sesame oil in the nostril can prevent the spreading of coronaviruses (Wen Fan et al., 2020). Sesame oil 
has high concentrations of unsaturated fatty acids such as linoleic and oleic acid that contribute the potential in prophylaxis and treatment against many bacterial infections (Dilika et al., 2000; Uzun et al., 2008).A bacterial infection is a serious health issue affecting millions of people worldwide every year. Increased antibiotic resistance against multiple drugs in different bacterial strains is posing a great threat worldwide thus limiting the antibiotic choice. Some studies have suggested that there is a considerable increase in the rate of antibiotic resistance in Saudi Arabia over a last few decades (Zowawi et al., 2016). Considering the role of unsaturated fatty acids against bacterial infections, Saudi sesame oil is a rich source of them and it can evaluated for its antibacterial activity against certain human pathogens.

\section{Material and Methods}

\section{Procurement of chemicals and Sesame oil}

Sesame seeds purchased from the local market of Jazan, Saudi Arabia. The standard sesame oil (SSO), media and broth purchased from Sigma Aldrich USA.

\section{Extraction of oil from sesame seeds}

Extraction of sesame oil was performed using cold press technique described by Kate et al. 2014. Approximately $500 \mathrm{~g}$ of sesame seeds were washed and dried in an oven under nitrogen at room temperature for $2 \mathrm{~h}$. The dried seeds were milled, kneaded, sparkled with warm water intermittently, and pressed to remove the oil. The oil was allowed to settle for $24 \mathrm{~h}$ and decanted in the clean container. The resulting oil was then filtered, centrifuged (3000 rpm for 5 minutes), separated named ESO and stored at $4^{\circ} \mathrm{C}$ in the refrigerator for further analysis.

\section{Physiochemical properties}

The extracted sesame oil (ESO) was evaluated for its physicochemical properties and compared with standard sesame oil (SSO). The specific gravity, acid value, iodine value, saponification value, solidification temperature of fatty acids and the unsaponifiable matter were determined by reported methods described by Olaleye et al.,2018 and USP general chapters 841 and 401 (US pharmacopeial convention 2015)

\section{GC/MS Analysis}

GCMS analysis of ESO and SSO was performed using Thermo Scientific GC/MS equipped with AS 3000 autosampler, trace ultra GC and $\mathrm{ISQ}^{\mathrm{TM}}$ detector. The separation was achieved using capillary TR-5MS column $(30 \mathrm{~m} \times 0.25 \mathrm{~mm}$ ID $\times$ $0.25 \mu \mathrm{m})$ and helium carrier gas at a flow rate of $1.2 \mathrm{ml} / \mathrm{min}$. The sesame oil was diluted 10 times $\mathrm{v} / \mathrm{v}$ with $\mathrm{n}$-hexane, filtered through $0.45 \mu \mathrm{m}$ PTFE filter and injected in splitless mode $(2 \mu \mathrm{L})$. The injection port was set at $320^{\circ} \mathrm{C}$ and temperature of the oven was initially set at $70^{\circ} \mathrm{C}$ with holding time for 5 minutes. The oven temperature was subsequently ramped to $205^{\circ} \mathrm{C}$ at a rate of $5^{\circ} \mathrm{C} / \mathrm{min}$ for 5 minutes, $280^{\circ} \mathrm{C}$ at a rate of $5^{\circ} \mathrm{C} / \mathrm{min}$ for 5 minutes, $290^{\circ} \mathrm{C}$ at a rate of $5^{\circ} \mathrm{C} / \mathrm{min}$ for 5 minutes, and finally to $300^{\circ} \mathrm{C}$ at a rate of $5^{\circ} \mathrm{C} / \mathrm{min}$ for 5 minutes. For GC-MS detection, an electron ionization system with ionization energy $70 \mathrm{eV}$ was used. Ion source and MS line transfer temperature were set at $320^{\circ} \mathrm{C}$ and $340^{\circ} \mathrm{C}$ respectively with $0.6 \mathrm{~s}$ scan time. The mass range of $60-900$ amu was selected using positive ion mode and spectra was recorded solvent delay time of 5 minutes to avoid initial solvent peaks. The mass spectra were interpreted using Xcalibur software and the fragmentation patterns of mass spectra were compared with those stored in the spectrometer database using the NIST, MAINLIB and REPLIB built-in libraries. The relative percentage amount of each component was calculated by comparing its average peak area to the total area.

\section{Compound identification}

The ESO was identified based on its physicochemical characteristics and comparedwith SSO. The experimentally determined values were also compared with those of standardpharmacopoeial values. The components of ESO and SSO were identified by using match factor (SI) and reverse match factor (RSI) thresholds of 900 and above between measured spectrum and standard library spectrum. Percentage areas of each component were obtained by using Xcalibur software without the use of any internal standard and are uncorrected.

\section{Antibacterial Analysis}

Standardization of bacterial cultures

Six bacterial strains namely Staphylococcus aureus (S. aureus), Streptococcus pyogenes (S. pyogenes), Bacillus subtilis (B. subtilis), Escherichia coli (E. 
coli), Pseudomonas aeruginosa (P. aeruginosa), and Klebsiella pneumoniae (K.pneumoniae) were used for this study was taken from the department of microbiology general hospital, Jazan. Briefly, 24 $\mathrm{h}$ culture was prepared and standardized by gradient dilution from $10^{-1}$ to $10^{-7}$ with nutrient broth. The viability of bacterial culture was identified by assessing colony forming unit in $1 \mathrm{ml}(\mathrm{CFU} / \mathrm{ml})$ as described Cappauccino and Sherman, 2014.

\section{Antibacterial spectrum analysis}

The antibacterial susceptibility test was done as established by Alam et al., 2016 and Moni et al., 2018. Briefly, Muller Hinton (MH) agar plates were prepared for performing the antibacterial study (Valgas, et. al., 2007).Bacterial subcultures were prepared from the stock culture and after $24 \mathrm{~h}$ incubation; the culture was subjected to antibacterial studies. Agar well diffusion technique was performed for sesame oil (ESO) and disc diffusion was utilized for ciprofloxacin disc (5 $\mathrm{mcg} / \mathrm{disc}$ ) as standard. The inoculation was done by dipping a sterile cotton swab into the standardized $(\mathrm{CFU} / \mathrm{ml})$ culture individually with various organisms and streaked on the $\mathrm{MH}$ agar plate by rotating the petri dish in order to distribute the culture evenly. The plates were allowed dried for about 10 minutes before administration of sesame oil (ESO). The agar well diffusion technique was performed by punching holes on the inoculated $\mathrm{MH}$ agar plates using standard sterile stainless-steel borer. The agar plates were incubated at $37^{\circ} \mathrm{C}$ for $24 \mathrm{~h}$ and the antibacterial spectrum was assessed by the development of inhibitory zones.

\section{Results and Discussion}

The sesame oil extracted from its seed by cold press technique (Kate et al., 2014) appeared as a light yellow color with a characteristic fragrant odor. The ESO was evaluated for its physicochemical properties and compared with SSO and standard codex values depicted in Table.1 (US pharmacopeial convention 2015).The results suggested that ESO and SSO conform to the specific tests listed in USP. Both ESO and SSO showed no reddish color on boiling with equal volumes of amyl alcohol and sulphur in carbondisulphide solution indicating the absence of the cottonseed oil (US pharmacopeial convention 2015).The GC-MS analysis of ESO and SSO revealed the presence of lignans, fatty acids, triglycerides, phytosterols, vitamins, triterpenes, steroids, hydrocarbons, fatty alcohols, and phenolic compounds. In ESO, a total of 35 compounds have been identified with the mass balance of $90.70 \%$ of total peak area (Figure 1) whereas SSO revealed a total of 38 compounds with the mass of $97.04 \%$ (Figure 2).The compounds with less than 900 SI and RSI are not reported. The details of all identified compounds with their retention time, molecular weight, molecular formula, and \% peak area etc. are represented in Table 2. The comparison of compounds between ESO and SSO showed that except for variation in the content of sesamin and some additional triglycerides observed in SSO, all other major components were observed at a similar level. Triglyceride, triolein was also not observed in SSO.(+)-Sesamin, a benzodioxole and a furofuranlignan, was found to be the predominant component (24.45\%) alongwith sesamol(17.91\%) in ESO. Both these components were observed in SSO with variation in the content of sesamin (28.24\%). They had been reported to have excellent antioxidant and the anti-bacterial activities thereby preventing the spoilage of food (Mahendra et al., 2015). The obtained quantities were similar to those reported in the literature with only slight variations. The quantity of these natural antioxidants showed variations with the country of origin but have similar chemical compositions indicating the role of environment or genetic conditions of the seeds (Carlsson et al., 2008). Linoleic acid (4\%) was found to be the main polyunsaturated fatty acid in ESO followed by oleic acid (3\%) (mono unsaturated fatty acid). The contents of saturated fatty acids, stearic acid, and palmitic acid were comparatively lesser than unsaturated fatty acid and were mainly observed as esters. These results are in good agreement with a high iodine value (106) of sesame oil suggesting more degree unsaturation in the ESO and SSO.The contents of saturated and unsaturated fatty acids obtained in ESO and SSO differed considerably from the literature (Were et al., 2006b; Uzun et al., 2008). The variations obtained could be attributed to extraction procedure employed by the author, use of FID detectors and derivatizing techniques for sample analysis. Triglycerides such as triolein $(0.64 \%)$, 2oleoglycerol (1.38\%), glycerol-1-palmitate 3-oleate $(1.5 \%)$ and 1,2-Dipalmitoyl-rac- 
Table 1. Comparison of physiochemical properties of extracted sesame oil (ESO), standard sesame oil (SSO) and United State Pharmacopeia (USP) value

\begin{tabular}{|l|l|l|l|}
\hline Parameters & $\begin{array}{l}\text { Extracted } \\
\text { Sesame oil (ESO) }\end{array}$ & $\begin{array}{l}\text { Standard Sesame } \\
\text { Oil (SSO) }\end{array}$ & $\begin{array}{l}\text { United State Pharmacopeia (USP) } \\
\text { Value }\end{array}$ \\
\hline Yield & $0.67 \%$ & -- & -- \\
\hline Specific gravity & 0.912 & 0.912 & 0.912 \\
\hline Color & Light Yellow & Light Yellow & Light Yellow \\
\hline $\begin{array}{l}\text { Acid Value (For free fatty } \\
\text { acid) }\end{array}$ & $1.9 \mathrm{~mL}$ & $1.9 \mathrm{~mL}$ & $\begin{array}{l}\text { NMT } 2.0 \mathrm{~mL} \text { of } 0.020 \mathrm{~N} \mathrm{NaOH} \\
\text { required for neutralization }\end{array}$ \\
\hline Iodine value & 110 & 112 & $103-116$ \\
\hline Saponification value & 190 & 191 & $188-195$ \\
\hline $\begin{array}{l}\text { Solidification temperature } \\
\text { for fatty acids }\end{array}$ & $23^{\circ} \mathrm{C}$ & $23^{\circ} \mathrm{C}$ & $20-25^{\circ} \mathrm{C}$ \\
\hline Unsaponifiable matter & $1.3 \%$ & $1.3 \%$ & NMT $1.5 \%$ \\
\hline Cotton seed oil & Not present & Not present & ---- \\
\hline
\end{tabular}

Table 2. Chemical compounds of Sesame oil sample (ESO) with their retention time, molecular weight, molecular formula, and \% peak area using GC/MS

\begin{tabular}{|c|c|c|c|c|c|c|}
\hline $\mathbf{S N}$ & RT & Name of Compound & $\begin{array}{l}\text { Molecular } \\
\text { Formula }\end{array}$ & $\begin{array}{l}\text { Molecular } \\
\text { Weight }\end{array}$ & $\begin{array}{l}\text { \% Peak } \\
\text { Area (ESO) }\end{array}$ & $\begin{array}{l}\text { \% Peak } \\
\text { Area (SSO) }\end{array}$ \\
\hline \multicolumn{7}{|c|}{ Lignans } \\
\hline 1 & 58.03 & $(+)$-Sesamin & $\mathrm{C} 20 \mathrm{H} 18 \mathrm{O} 6$ & 354 & 24.45 & 28.92 \\
\hline 2 & 59.16 & Sesamol & C7H6O3 & 138 & 17.91 & 17.98 \\
\hline \multicolumn{7}{|c|}{ Fatty acids and triglycerides } \\
\hline 3 & 37.33 & Linoleic acid & $\mathrm{C} 18 \mathrm{H} 32 \mathrm{O} 2$ & 280 & 4.01 & 4.02 \\
\hline 4 & 37.00 & Oleic acid & $\mathrm{C} 18 \mathrm{H} 34 \mathrm{O} 2$ & 282 & 3.01 & 3.01 \\
\hline 5 & 40.10 & $\begin{array}{l}\text { Stearyloleate (Oleic acid } \\
\text { octadecyl ester) }\end{array}$ & $\mathrm{C} 36 \mathrm{H} 70 \mathrm{O} 2$ & 534 & 1.51 & 1.52 \\
\hline 6 & 44.26 & 3-Hydroxypropyl oleate & $\mathrm{C} 21 \mathrm{H} 40 \mathrm{O} 3$ & 340 & 0.57 & 0.56 \\
\hline 7 & 45.21 & $\begin{array}{l}\text { 2-Monoolein; 2-Oleoylglycerol } \\
\text { (Oleic acid 2-hydroxy-1- } \\
\text { (hydroxymethyl)ethyl ester) }\end{array}$ & $\mathrm{C} 21 \mathrm{H} 40 \mathrm{O} 4$ & 356 & 1.38 & 1.38 \\
\hline 8 & 62.09 & Eicosyloleate & $\mathrm{C} 38 \mathrm{H} 74 \mathrm{O} 2$ & 562 & 0.15 & 0.14 \\
\hline 9 & 63.56 & Glycerol 1-palmitate 3-oleate & $\mathrm{C} 37 \mathrm{H} 70 \mathrm{O} 5$ & 594 & 1.51 & 1.49 \\
\hline 10 & 41.36 & 1,2-Dipalmitoyl-rac-glycerol & $\mathrm{C} 35 \mathrm{H} 68 \mathrm{O} 5$ & 568 & 1.62 & 1.59 \\
\hline 11 & 68.17 & Triolein & C57H104O6 & 885 & 0.64 & $\mathrm{NF}$ \\
\hline 12 & 68.12 & $\begin{array}{l}\text { 1,2-dilinoleoyl-3-oleoyl-rac- } \\
\text { glycerol }\end{array}$ & C57H100O6 & 881 & $\mathrm{NF}$ & 0.32 \\
\hline 13 & 65.81 & $\begin{array}{l}\text { 1,2-dioleoyl-3-linoleoyl-rac- } \\
\text { glycerol }\end{array}$ & C57H102O6 & 883 & $\mathrm{NF}$ & 0.42 \\
\hline 14 & 67.89 & Trilinolein & C57H98O6 & 879 & NF & 0.18 \\
\hline 15 & 65.12 & $\begin{array}{l}\text { 1,2-dioleoyl-3-palmitoyl-rac- } \\
\text { glycerol }\end{array}$ & C55H102O6 & 859 & NF & 0.21 \\
\hline \multicolumn{7}{|c|}{ Phytosterols } \\
\hline 16 & 58.58 & Campesterol & $\mathrm{C} 28 \mathrm{H} 48 \mathrm{O}$ & 400 & 4.10 & 4.09 \\
\hline 17 & 60.46 & $\beta$-Sitosterol & $\mathrm{C} 29 \mathrm{H} 50 \mathrm{O}$ & 414 & 16.13 & 16.12 \\
\hline \multicolumn{7}{|c|}{ Triterpene } \\
\hline 18 & 50.74 & Squalene & $\mathrm{C} 30 \mathrm{H} 50$ & 410 & 0.23 & 0.24 \\
\hline \multicolumn{7}{|c|}{ Phenolic volatile oil } \\
\hline 19 & 18.49 & Eugenol & $\mathrm{C} 10 \mathrm{H} 12 \mathrm{O} 2$ & 164 & 0.12 & 0.13 \\
\hline
\end{tabular}


Chemical characterization and antibacterial efficacy of Saudi sesame

\begin{tabular}{|c|c|c|c|c|c|c|}
\hline \multicolumn{6}{|c|}{ Vitamin E } & \multirow[b]{2}{*}{4.48} \\
\hline 20 & 54.75 & Gamma-Tocopherol & $\mathrm{C} 28 \mathrm{H} 48 \mathrm{O} 2$ & 416 & 3.46 & \\
\hline \multicolumn{7}{|c|}{ Aliphatic hydrocarbons } \\
\hline 21 & 19.20 & 1-Hexadecene & $\mathrm{C} 16 \mathrm{H} 32$ & 224 & 0.12 & 0.13 \\
\hline 22 & 32.76 & 1-Nonadecene & C19H38 & 266 & 0.34 & 0.35 \\
\hline 23 & 43.49 & Heptacosane & C27H56 & 380 & 0.70 & 0.69 \\
\hline 24 & 47.31 & Heneicosane & $\mathrm{C} 21 \mathrm{H} 44$ & 296 & 1.07 & 1.09 \\
\hline 25 & 50.55 & Pentacosane & $\mathrm{C} 25 \mathrm{H} 52$ & 352 & 1.23 & 1.24 \\
\hline 26 & 52.95 & Tetratetracontane & C44H90 & 618 & 0.20 & 0.20 \\
\hline \multicolumn{7}{|c|}{ Aliphatic alcohols } \\
\hline 27 & 24.20 & 1-Hexadecanol & $\mathrm{C} 16 \mathrm{H} 34 \mathrm{O}$ & 242 & 0.35 & 0.35 \\
\hline 28 & 28.66 & 1-Hexadecenol, & $\mathrm{C} 16 \mathrm{H} 32 \mathrm{O}$ & 240 & 0.37 & 0.58 \\
\hline 29 & 38.40 & 1-Eicosanol & $\mathrm{C} 20 \mathrm{H} 42 \mathrm{O}$ & 298 & 0.32 & 0.33 \\
\hline \multicolumn{7}{|c|}{ Aromatic hydrocarbons } \\
\hline 30 & 7.29 & Trimethyl benzene (mixture) & C9H12 & 120 & 1.86 & 1.87 \\
\hline 31 & 10.02 & 4-Ethyl-1,2-dimethylbenzene & $\mathrm{C} 10 \mathrm{H} 14$ & 134 & 0.15 & 0.15 \\
\hline 32 & 21.26 & 2-Methoxynaphthalene & $\mathrm{C} 11 \mathrm{H} 10 \mathrm{O}$ & 158 & 0.14 & 0.15 \\
\hline 33 & 22.38 & 2,4-bis(1,1-dimethylethyl)-Phenol & $\mathrm{C} 14 \mathrm{H} 22 \mathrm{O}$ & 206 & 0.36 & 0.36 \\
\hline 34 & 49.79 & Di-(2-ethylhexyl)-tetraphthalate & $\mathrm{C} 24 \mathrm{H} 38 \mathrm{O} 4$ & 390 & 0.38 & 0.40 \\
\hline \multicolumn{7}{|c|}{ Steroids } \\
\hline 35 & 53.83 & $\begin{array}{l}\text { 2-(3-acetoxy-4,4,14- } \\
\text { trimethylandrost-8-en-17-yl) } \\
\text { propanoate }\end{array}$ & $\mathrm{C} 27 \mathrm{H} 42 \mathrm{O} 4$ & 430 & 0.37 & 0.36 \\
\hline 36 & 60.75 & $\begin{array}{l}\text { 24-propylidene-(3ß)-Cholest-5- } \\
\text { en-3-ol }\end{array}$ & $\mathrm{C} 30 \mathrm{H} 50 \mathrm{O}$ & 426 & 1.11 & 1.12 \\
\hline 37 & 61.01 & 4-Pregnen-6 $\beta, 17 \beta$-diol-3,20-dione & $\mathrm{C} 21 \mathrm{H} 30 \mathrm{O} 4$ & 346 & 0.26 & 0.25 \\
\hline 38 & 61.30 & $\begin{array}{l}\text { (3ß)- Stigmasta-5,24(28)-dien-3- } \\
\text { ol, }\end{array}$ & $\mathrm{C} 29 \mathrm{H} 48 \mathrm{O}$ & 412 & 0.32 & 0.31 \\
\hline 39 & 63.79 & $\begin{array}{l}\text { 21-hydroxy-Pregn-4-ene-3,11,20- } \\
\text { trione }\end{array}$ & $\mathrm{C} 21 \mathrm{H} 28 \mathrm{O} 4$ & 344 & 0.31 & 0.31 \\
\hline
\end{tabular}

Table 3. Chemical structures of main components present in extracted sesame oil (ESO) using gas chromatography mass spectrometry (GCMS)

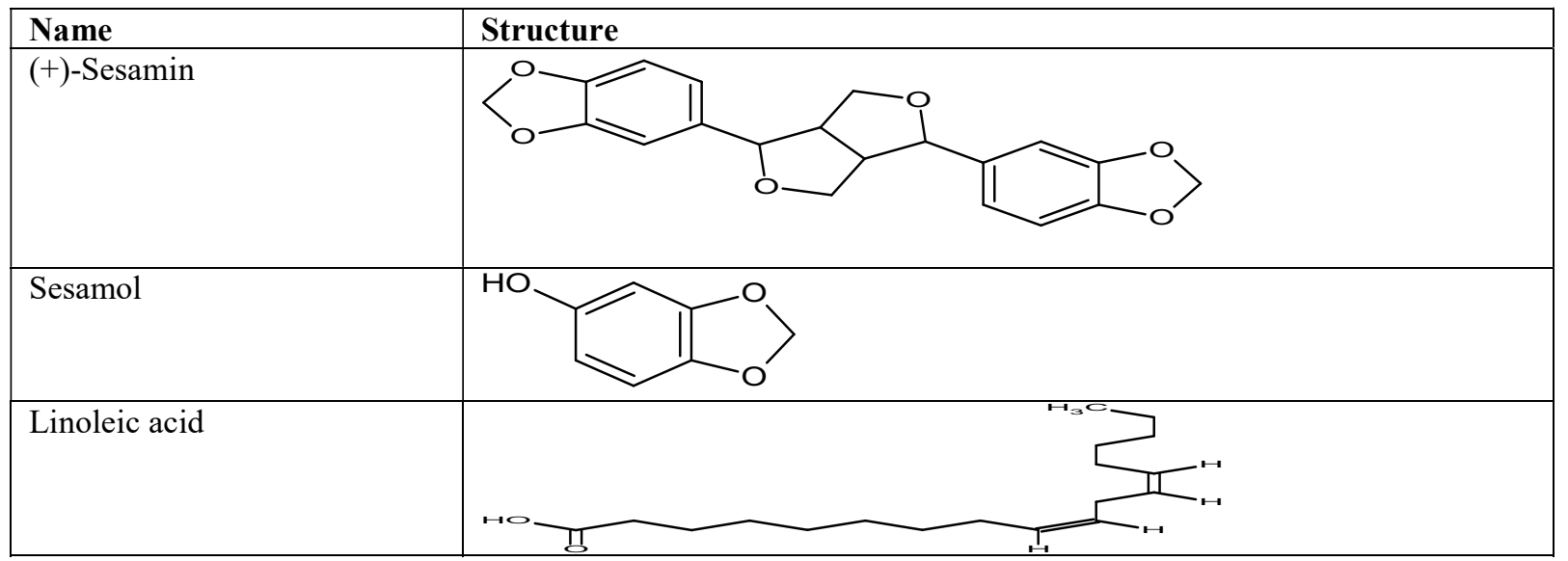


Alshahrani et al.

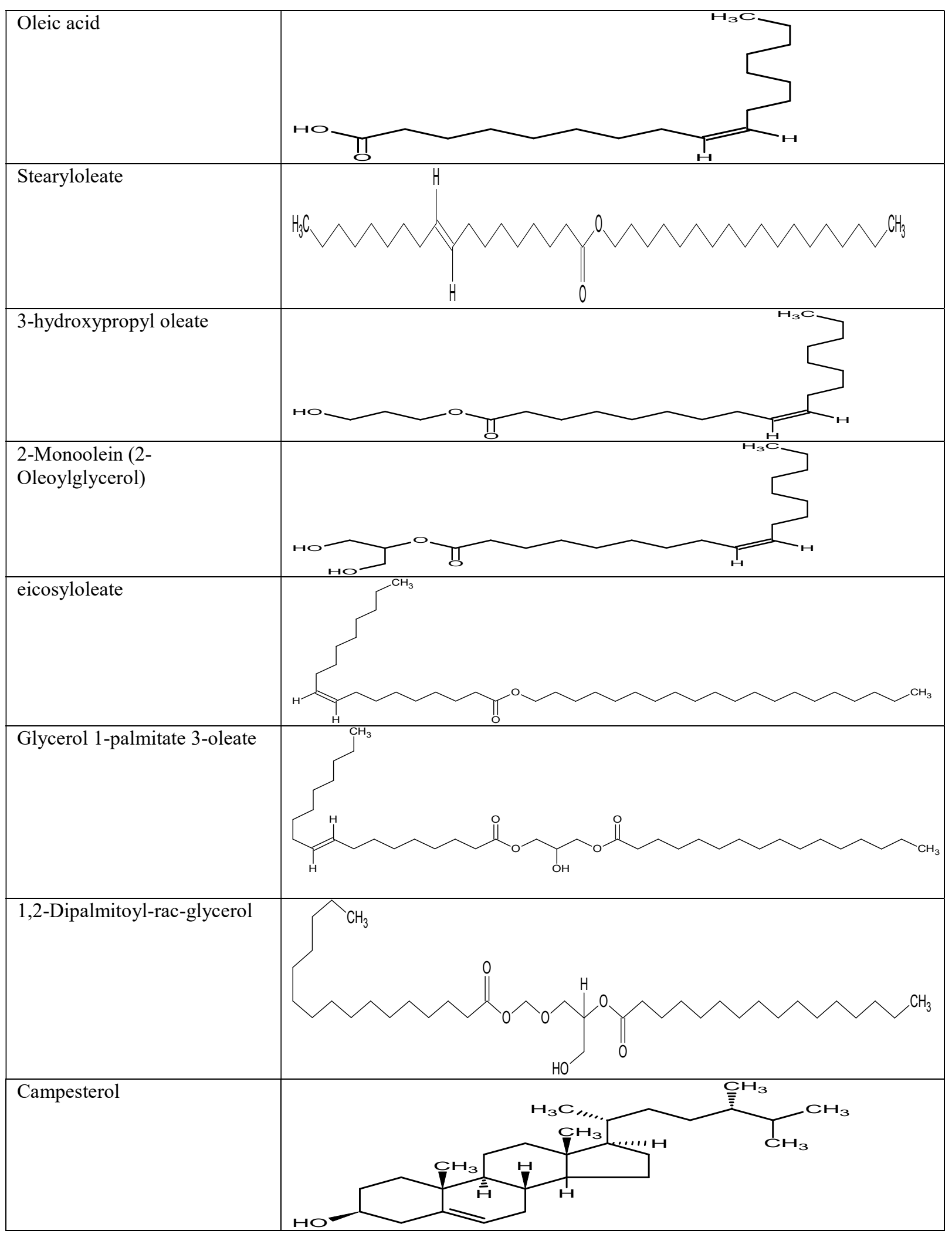




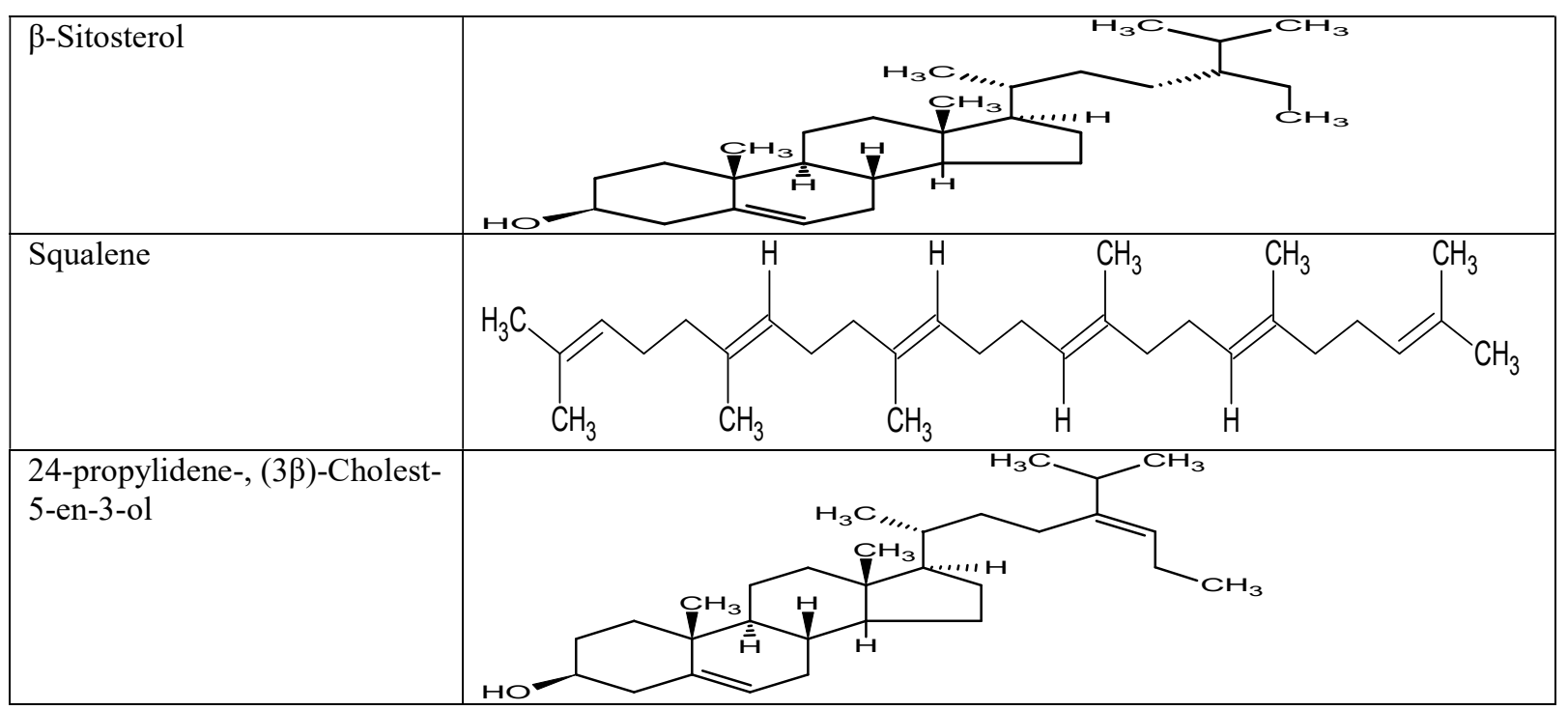

Table 4. Antibacterial effects of sesame oil (ESO) against human pathogenic bacteria

\begin{tabular}{|c|c|c|c|}
\hline \multirow[t]{2}{*}{ Organisms } & \multirow{2}{*}{$\begin{array}{l}\text { Concentration of } \\
24 \text { h culture } \\
(\mathrm{cfu} / \mathrm{ml})\end{array}$} & \multicolumn{2}{|c|}{$\begin{array}{c}\text { Zone Of Inhibition in }(\mathbf{m m}) \\
(\text { Mean } \pm \text { S.D)* }\end{array}$} \\
\hline & & Local Sesame Oil & $\begin{array}{l}\text { Ciprofloxacin } \\
(5 \mu g / \text { disc })\end{array}$ \\
\hline Bacillus subtilis & $2 \times 10^{-5}$ & $18.7 \pm 1.2$ & $27.2 \pm 1.2$ \\
\hline Staphylococcus aureus & $3 \times 10^{-4}$ & $25 \pm 1.7$ & $26.6 \pm 1.3$ \\
\hline Streptococcus pyogenes & $3 \times 10^{-4}$ & $22.3 \pm 2.5$ & $24.16 \pm 0.4$ \\
\hline Escherichia coli & $2 \times 10^{-5}$ & $27.3 \pm 1.5$ & $28 \pm 2.1$ \\
\hline Pseudomonas aeruginosa & $2 \times 10^{-4}$ & $12.7 \pm 1.15$ & $26.6 \pm 0.6$ \\
\hline Klebsiella pneumoniae & $2 \times 10^{-4}$ & $14.6 \pm 2.11$ & $28.8 \pm 1.3$ \\
\hline
\end{tabular}

\footnotetext{
* Each value is the mean of six batches with standard deviation.
}

glycerol $(1.6 \%)$ were also present in considerable quantities in ESO.Interestingly, some additional triglycerides such as 1,2-dilinoleoyl-3-oleoyl-racglycerol $(0.32 \%), \quad$ 1,2-dioleoyl-3-linoleoyl-racglycerol $(0.42 \%)$, trilinolein $(0.18 \%)$ and $1,2-$ dioleoyl-3-palmitoyl-rac-glycerol $\quad(0.21 \%)$ were also observed in SSO. Amongst phytosterols, betasitosterol $(16.13 \%)$ and campesterol $(4.10 \%)$ were present in good quantities indicating the role of sesame oil in alteration of lipid metabolism and exhibiting more potent cholesterol-reducing effect (Deme et al., 2018). The antioxidant, vitamin $\mathrm{E}$ $(3.46 \%)$ (gamma-tocopherol) was also present there by making the sesame oil as a good carrier for other essential oils. The terpenes, such as squalene $(0.23 \%)$ and eugenol $(0.12 \%)$ were also present in small quantities, responsible for aroma and flavor of sesame oil. Other bioactive components such as substituted xanthines, phenols and naphthols, steroids, fatty alcohols and hydrocarbons were also present.The structures of major components observed in ESO are depicted in Table 3.

Bacterial resistance is the major threat against various antibiotics and antibacterial drug of the current therapeutic era (Cohen, 1992; Nascimento, et al., 2000).Therefore, developing a novel 


\section{Alshahrani et al.}

antibacterial or the antibiotic molecule is very important in the current therapeutic world. Unfortunately, there is no assurance that new molecules never develop resistance and become inactive. In this connection, bioactive substances from the herbal origin are an alternative source for developing antibacterial which has been focused by various researchers across the world for the past three decades.In this study, the effectiveness of cold press extract of sesame oil was screened against certain human pathogenic bacteria for demonstrating the potentiality. The results are summarized in Table.4 demonstrating the potential efficacy of extracted sesame oil against grampositive bacteria including $S$. aureus, $S$. pyogenes, B. subtilis, and Gram-negative bacteria includes E. coli, $K$. pneumoniae, $P$. aeruginosa. The spectrum of activity was directly proportional to the diameter of the zones of inhibition. The study demonstrates that the extracted sesame oil exhibited a wide spectrum of activity against Gram-positive and Gram-negative bacteria but predominant activity was observed against E. coli, S. aureus, and $S$. pyogenes. Bawazir et al., (2018) reported the antibacterial potential of Yamni sesame oil against pathogenic bacteria such as Escherichia coli, Staphylococcus aureus, Salmonella typhi, Candida albicans, and fungi strains such as Aspergillus niger and Aspergillus flavus. Furthermore, their report indicated that Semsumsanani and Semsumdwaini showed better antifungal activity against Aspergillus niger and Aspergillus flavus when compared to bacterial strains. Interestingly, the oil of Semsumshahri and Semsumhadedi did not show any potential activity against bacteria or fungi (Bawazir et al., 2018). The Saudi sesame oil results are more prompt and effective against certain

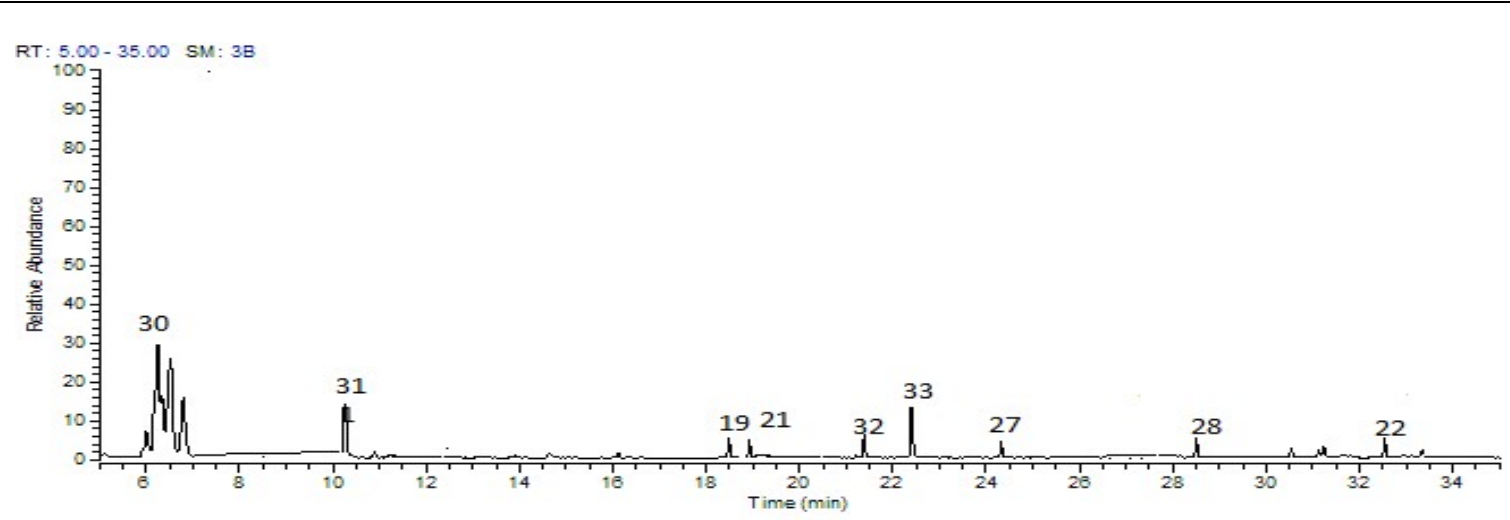

A: Total ion chromatogram from $5-35$ minutes

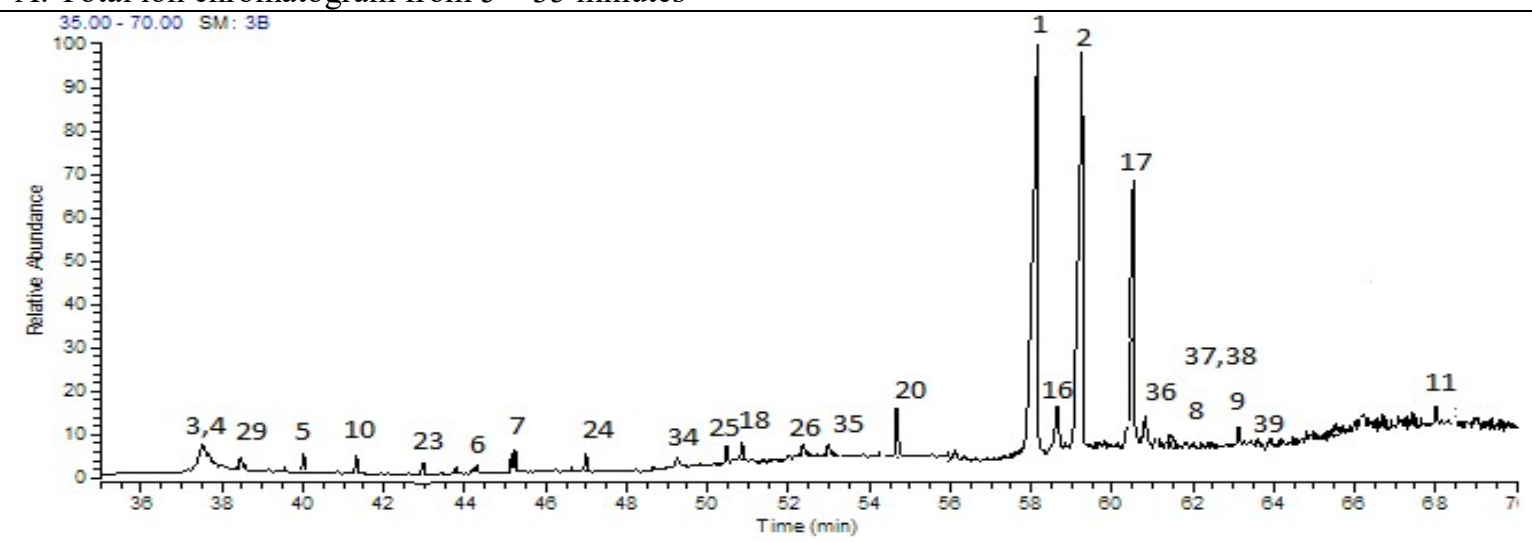

B: Total ion chromatogram from $35-70$ minutes

Figure 1. Chemical compounds of Extracted Sesame Oil (ESO) using gas chromatography mass spectrometry (GCMS) 


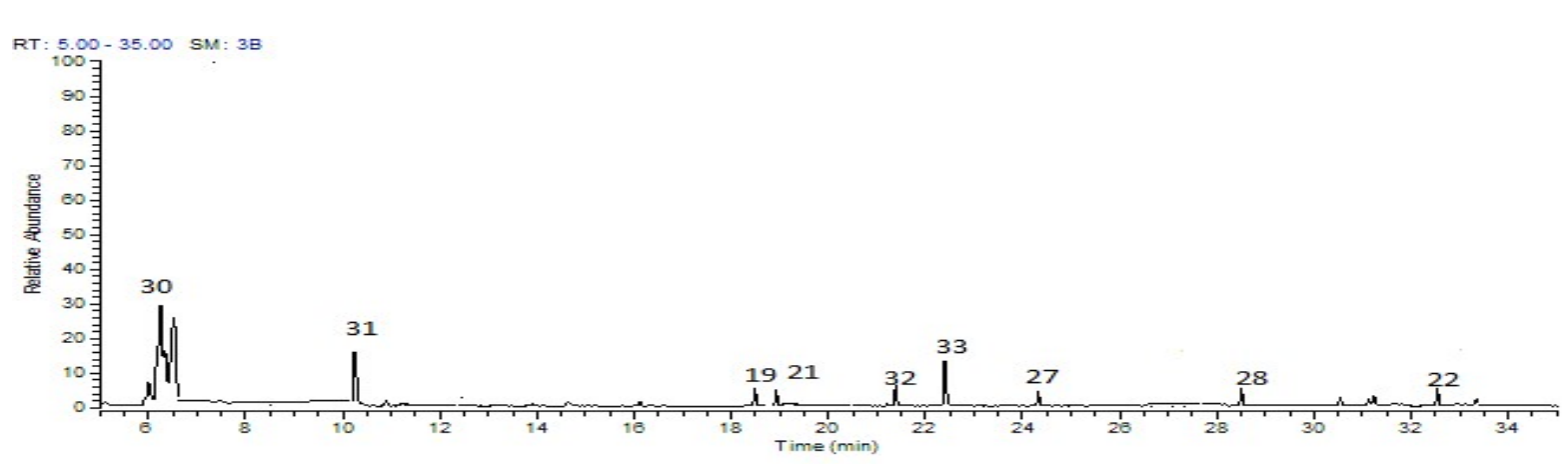

A: Total ion chromatogram from $5-35$ minutes

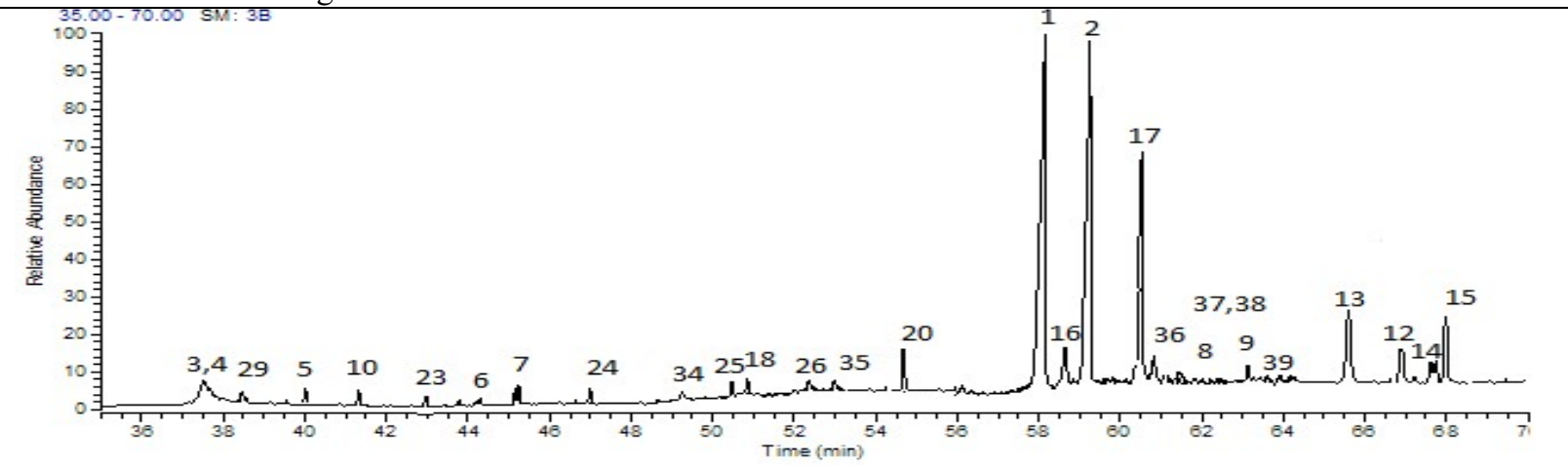

B: Total ion chromatogram from $35-70$ minutes

Figure 2. Chemical compounds of Standard Sesame oil (SSO) using gas chromatography mass spectrometry (GCMS).

pathogenic bacteria. Some studies have shown that relationship exists between the chemical structures of the most abundant compounds in the tested extracts or essential oils and the antimicrobial activity (Farag et al., 1989). Shitu et al., 2007 reported the antimicrobial activity of sesame oil against skin pathogen such as staphylococcus and streptococcus as well as some fungus (Shitu et al., 2007a). Some other researchers also reported the comparative studies of the crude extracts of sesame leaves against common pathogenic bacteria and found a high level of inhibition for most of the microorganism except $S$. aureus (Ahmad et al., 2009). Thus, sesame oil from Saudi Arabia showed the spectrum of activity against certain human pathogenic bacteria that had been screened in this study.

\section{Conclusions}

The present findings indicated that sesame essential oils are effective against certain selected pathogenic bacteria as it may be a component of antibacterial formulation that will help to minimize the bacterial infection problem in Saudi Arabia.

\section{Acknowledgements}

We are thankful to Deanship of Scientific Research, Jazan University for providing the financial assistant (FR6-44).

\section{Disclosure statement}

The authors have no conflict of interest.

\section{Funding}

The research reported in this study was supported by the Deanship of Scientific Research, Jazan University.

\section{References}

Ahmed, T., Shittu, L.A.J., Bankole, Shittu, R.K., Adesanya, O.A., Bankole, M.N., Ashiru, O.A., 2009. Comparative studies of the crude extracts of sesame against some common pathogenic microorganisms. Scientific Research and Essays, 4(6): 584-589. 
Alam, M.F., Safhi, M.M., Moni, S.S., Jabeen, A., 2016. In Vitro Antibacterial Spectrum of Sodium Selenite against Selected Human Pathogenic Bacterial Strains. Scientifica, 2016: 1-4.

Al-Attar, A.M., Elnaggar, M.H.R., Almalki, E.A., 2017. Protective effect of some plant oils on diazinon induced hepatorenal toxicity in male rats. Saudi Journal of Biological Sciences, 24(6): 1162-1171.

Al-Turki, T.A., Al-Namazi, A. A., Masrahi, Y.S., 2019. Conservation of genetic resources for five traditional crops from Jazan, SW Saudi Arabia, at the KACST Gene-Bank. Saudi Journal of Biological Sciences, 26:1626-1632.

Bawazir, A.M.A., Shantaram, M., 2018. Effect Of Yemeni Sesame Oil Against Some Pathogenic Bacteria and Fungi. International Journal of Pharmaceutical Science and Research, 9(6): 2507-2512.

Cappauccino JG, Sherman N. 2014. Microbiology - A laboratory manual, $10^{\text {th }}$ edition, Pearson Education.

Carlsson, A.S., Chanana, N.P., Gudu, S., Suh, M.C., Were, B.A., 2008. Sesame. In: Kole C, et al., (Eds.) Compendium of transgenic crop plant- Transgenic oilseed crops. Texas, USA: Wiley Blackwell, pp.227-246.

Cohen, M.L., 1992. Epidemiology of drug resistance: implications for a post antimicrobial era. Science, 257(5073):1050-1055.

Deme, P., Narasimhulu, C.A., Parthasarathy, S., 2018. Identification and evaluation of anti-Inflammatory properties of aqueous components extracted from sesame (SesamumIndicum) oil. Journal of Chromatography B Analytical Technology and Biomedical Life Science, 1087-1088: 61-69, 2018.

Dilika, F., Bremner, P.D., Meyer, J.J., 2000. Antibacterial activity of linoleic and oleic acids isolated from Helichrysumpedunculatum: a plant used during circumcision rites, Fitoterapia, 71(4):450-4522.

Farag, R.S., Daw, Z.Y., Hewedi, F.M., El-Baroty, G.S.A., 1989. Antimicrobial activity of some Egyptian spice essential oils. Journal of Food Product 52(9):665-667.

Kate, A.E., Lohani, U.C., Pandey, J.P., Shahi. N.C., Sharkar, A., 2014. Traditional and mechanical method of the oil extraction from wild apricot kernel: A comparative study. Research Journal of Chemistry and Environmental Science, 2(2): 54-60.

Koshak, A.E., 2019. Prevalence of herbal medicines in patients with chronic allergic disorders in Western Saudi Arabia. Saudi Medical Journal, 40(4): 391-396.
Journal of Food Science and Technology, 52(5): 29342941.

Majdalawieh, A.F., and Mansour, Z.R., 2019. Sesamol, a major lignan in sesame seeds (Sesamumsindicum): Anti-cancer properties and mechanisms of action. European Journal of Pharmacology, 855: 75-89.

Mekky, R.H., Abdel-Sattar, E., Segura-Carretero, A., Contreras, M.D.M., 2019. Phenolic Compounds from Sesame Cake and Antioxidant Activity: A New Insight for Agri-Food Residues' Significance for Sustainable Development. Foods, 8(10):432.

Moni, S.S., Alam, M.F., Safhi, M.M., Jabeen, A., Sanobar, S., Siddiqui, R., Moochikkal, R., 2018. Potency of nanoantibacterial formulation from Sargassumbinderi against selected human pathogenic bacteria. Brazilain Journal of Pharmceutical Sciences, 54(4): 1-9.

Narasimhulu, C.A., Riad, A., Parthasarathy, S., 2018. Sesame Oil and an Aqueous Extract Derived from Sesame Oil Enhance Regression of Preexisting Atherosclerotic Lesions in Low-Density Lipoprotein Receptor Knockout Mice. Journal of Medicine and Food, 21(7): 641-646.

Nascimento, G.F., Locatelli, J., Freitas, P.C., Silva,G.L., 2000. Antibacterial activity of plant extracts and phytochemicals on antibiotic resistant bacteria. Brazilian Journal of Microbiology, 31(4): 247-256.

Olaleye, O.O., Kukwa, R.E., Eke, M.O., Aondo,T.O., 2018. Extraction, Physicochemical and Phytochemical Characterization of Oil from Sesame Seed. Asian Food Science Journal, 1(4): 1-12.

Özcan, M.M., Al-Juhaimi, F., 2015. Effect of date (Phoenix dactylifera L.) seed extract on stability of olive oil. Journal of Food Science and Technology, 52(2): 1218-1222.

Ruankham, W., Suwanjang, W., Wongchitrat, P., Prachayasittikul, V., Prachayasittikul S., Phopin, K. 2019. Sesamin and sesamol attenuate $\mathrm{H} 2 \mathrm{O} 2 \mathrm{q}$-induced oxidative stress on human neuronal cells via the SIRT1-SIRT3FOXO3a signaling pathway. Nutritional Neuroscience, 30:1-12.

Shittu, L.A.J., Bankole, M.A., Ahmed, T., Bankole, M.N., Shittu, R.K., Saalu, C.L., Ashiru, O.A., (2007a). Antibacterial and Antifungal Activities of Essential Oils of Crude Extracts of Sesame Radiatum against Some Common Pathogenic Microorganisms. Iranian Journal of Pharmacology and Therapeutics, 6:165-170.

USP Sesame oil 2015, The United States Pharmacopeial Convention, Interim Revision Announcement, USP (2015). $1-2$.

Uzun, B., Arslan, C., Furat, S., 2008. Variation in fatty acid compositions, oil content, and oil yield in germplasm
Mahendra, K.C., Sridevi, A.S., 2015. Bioactive lignans from sesame (Sesamumindicum L.): evaluation of their antioxidant and antibacterial effects for food applications. 
collection of sesame (Sesamumindicum L). Journal of American Oil Chemical Society, 85(12):1135-1142.

Valgas, C., De Souza, S.M., Smânia, E.F.A., Smania Jr, A., 2007. Screening methods to determine antibacterial activity of natural products. Brazillian Journal of Microbiology, 38: $369-380$.

Wen Fan, Jing Zeng, Yunfeng Xu., 2020. Atheoretical discussion of the possibility and possible mechanisms of using sesame oil for prevention of 2019-nCoV (Wuhan coronavirus) from the perspective of colloid and interface science Preprint Research Gate, doi:10.13140/RG.2.2.31786.98248

Were, B.A., Onkware, A.O., Gudu, S., Welander, M., Carlsson, A.S., 2006b. Seed oil content and fatty acid composition in East African sesame (Sesamumindicum L.) accessions evaluated over 3 years. Field Crops research, 97(2-3):254260.

Zowawi, H.M., 2016. Antimicrobial resistance in Saudi Arabia. An urgent call for an immediate action.Saudi Medical Journal, 37(9): 935-940. 